\title{
CLIMATE CHANGE AND ORGANIC AGRICULTURE
}

\author{
Ram Chandra Khanal ${ }^{1}$
}

\begin{abstract}
This paper attempts to explore some research findings focusing on the climate change impact on (organic) agriculture and agriculture impact on climate change through a literature review. This review reveals that climate change and agriculture are closely linked and interdependent. Compared to conventional agriculture, organic agriculture is reported to be more efficient and effective both in reducing $\mathrm{GHGs}\left(\mathrm{CO}_{2}, \mathrm{CH}_{4}\right.$ and $\left.\mathrm{N}_{2} \mathrm{O}\right)$ emission mainly due to the less use of chemical fertilizers and fossil fuel. Organic agriculture also reported to be climate change resilience farming systems as it promotes the proper management of soil, water, biodiversity and local knowledge there by acting as a good options for adaptation to climate change. But, due to lack of proper research, the contribution of organic agriculture for climate change adaptation and mitigation is yet to be known in the Nepalese context. It is argued that organic agriculture positively contributes to offset negative impacts of climate change, but there is inadequate systematic data to substantiate this fact.
\end{abstract}

Key words: adaptation, climate change, greenhouse gases mitigation, organic agriculture,

\section{INTRODUCTION}

Climate change is a natural process but recent trends related to climate change are alarming mainly due to anthropogenic reasons. Climate change has already affected people, their livelihoods and ecosystems and presents a great development challenge for the global community in general and for the poor people in developing countries in particular.

The level of greenhouse gases (GHGs) - mainly carbon dioxide $\left(\mathrm{CO}_{2}\right)$, nitrous oxide $\left(\mathrm{N}_{2} \mathrm{O}\right)$ and methane $\left(\mathrm{CH}_{4}\right)$ - have been rapidly increasing after the industrial revolution. The increased level of GHGs has created a greenhouse effect which subsequently altered precipitation patterns and global temperatures around the world. Impacts have been witnessed in several areas due to change in precipitation and temperature. The impact areas include, including others, agriculture, forestry, water resources, biodiversity, desertification, human health, and ecosystems goods and services globally. Researches revealed that rate and extent of climate change effects have increased significantly over the years with the increasing climate variability and extreme events.

Clear impacts from climate change are being witnessed in agriculture. Impacts are both positive as well as negative. They are, however dependent on latitude, altitude and type of crop. There have been noticeable impacts on plant production, insect, disease and weed dynamics, soil properties and microbial compositions in farming systems. According to IPCC 2007a, a temperature change in tropical areas has in general had a negative impact on food production and it is estimated that food production within South Asia will decrease by about $30 \%$ by 2050 .

Although causes and effect relations of climate change and agriculture are seen many forms and extent, assessment of those relations and effects of climate change on agriculture and the impact of (both conventional and organic) agriculture on climate change are not properly

\footnotetext{
${ }^{1}$ Ecological Services Centre, ecoscentre@wlink.com.np
} 
documented. Understanding of these nexus is vital not only to improve the agricultural sector productivity but it is also important to positively contribute to the environmental management regime at large.

In this backdrop, global communities are in a quest of identifying more efficient farming practices which reduce GHGs emissions (mitigation) as well act as resilient systems that able to adapt impacts of climate change (adaptation). Organic agriculture is being considered as one of the appropriate farming systems that could serve the twin objectives of climate change mitigation and adaptation.

\section{Box 1: Major findings of IPCC 2007}

Crop productivity is projected to increase slightly at mid to high latitudes for local mean temperature increases of up to $1-3^{\circ} \mathrm{C}$ depending on the crop, and then decrease beyond that in some regions.

At lower latitudes, especially seasonally dry and tropical regions, crop productivity is projected to decrease for even small local temperature increases $\left(1-2^{\circ} \mathrm{C}\right)$, which would increase risk of hunger.

Globally, the potential for food production is projected to increase with increases in local average temperature over a range of $1-3^{\circ} \mathrm{C}$, but above this it is projected to decrease.

Increases in the frequency of droughts and floods are projected to affect local crop production negatively, especially in subsistence sectors at low latitudes.

It is projected that crop yields could increase up to $20 \%$ in East and Southeast Asia while they could decrease up to $30 \%$ in Central and South Asia by the mid-21st century. Taken together and considering the influence of rapid population growth and urbanization, the risk of hunger is projected to remain very high in several developing countries.

\section{OBJECTIVES}

This paper attempts to inquire climate change - (organic) agriculture nexus in order to integrate sustainable agriculture issues in agriculture and climate change policies by initiating policy dialogues. The specific objectives of this paper were to explore effect of climate change on agriculture and how organic agriculture could contribute in climate change mitigation and adaptation to climate change.

\section{METHODS AND SCOPE}

This paper is based on a desk review of available literature. Data related to climate change, agriculture and organic agriculture is very limited in Nepal and in other south Asian countries; hence information was accessed mainly through web search and it is presented primarily for raising awareness and policy discussions. Some personal observations and views were also captured. 


\section{AGRICULTURAL IMPACTS ON CLIMATE CHANGE}

Agriculture is one of important contributors of GHG emissions at the global scale. Agricultural land use in the 1990s was responsible for approximately 15\% of all GHG emissions (Organic Consumer Association, 2008). Another report produced by OECD (2001) stated that agriculture contributes to over $20 \%$ of global anthropogenic greenhouse gas emissions (Food and Agriculture Organization, 2008).

According to the World Bank (2008), agriculture contributes about half of the global emissions of two of the most potent non-carbon dioxide greenhouse gases: nitrous oxide and methane (World Bank, 2008). Livestock manure, nitrogenous fertilizers and irrigated paddy are said to be responsible for producing most agricultural nitrous oxide and methane emissions. These non-carbon GHGs have more powerful greenhouse effects and have greater longevity than carbon dioxide. The different sources of GHGs and the role of the agricultural sector are presented in figures 1 and 2 (Research Institute of Organic Agriculture, 2008).

Agricultural intensification mainly in developed countries after World War II has consumed heavy amounts of fossil fuels and other inputs, contributing significantly to GHG emissions. The doubling of GHG production during the last 35 years was associated with a 6.9 fold increase in nitrogen fertilization, a 3.5 fold increase in phosphorus fertilization and a 1.7 fold increase in irrigated land (food and Agriculture Organization, 2008). The increase of chemical fertilizers contributed substantial amount of GHGs emissions.

Nitrous oxide emissions not only contribute to the greenhouse effect but also to the depletion

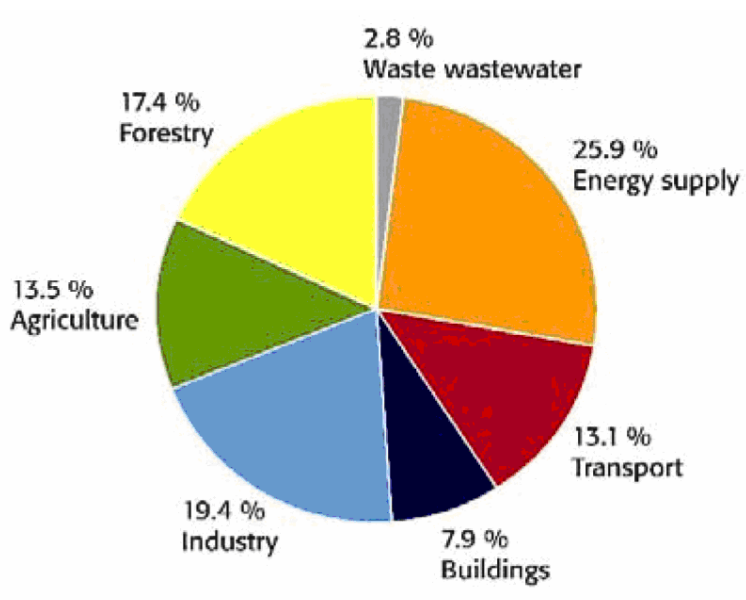

of stratospheric ozone. Almost $90 \%$ of the global atmospheric $\mathrm{N}_{2} \mathrm{O}$ is formed during the microbial transformation of nitrate $\left(\mathrm{NO}_{2}{ }^{-}\right)$and ammonia $\left(\mathrm{NH}_{4}{ }^{+}\right)$in soils and water. Globally, agriculture contributes $65-80 \%$ of total $\mathrm{N}_{2} \mathrm{O}$, mainly from nitrogenous fertilizers on cultivated soils, cattle and feedlots. $\mathrm{N}_{2} \mathrm{O}$ emissions from soils are due to the unproductive loss of mobile N. Any nitrogen input (mineral and organic fertilizers, biologically fixed $\mathrm{N}$, crop residues) and the mineralization of nitrogen compounds in soils, contribute to the emission of $\mathrm{N}_{2} \mathrm{O}$. Especially in agricultural soils, elevated $\mathrm{N}_{2} \mathrm{O}$ production depends on the nitrogen fertilization level

Figure 1. Green House Gas emissions

Agriculture is believed to account for roughly two-thirds of the total man-made methane $\left(\mathrm{CH}_{4}\right)$ emissions; mainly from paddy rice fields, burning of biomass and ruminants (enteric fermentation and animal waste treatment). Aerobic agricultural soils, however, are considered sinks for atmospheric $\mathrm{CH}_{4}$.

Nepal's contribution to GHGs emissions is about $0.025 \%$ of the global total. (MoPE, 2004). The 1994/5 National Greenhouse Gas Inventory Study of Nepal revealed the gas emission as below 
Figure 2: Main sources of GHGs from agriculture -2005

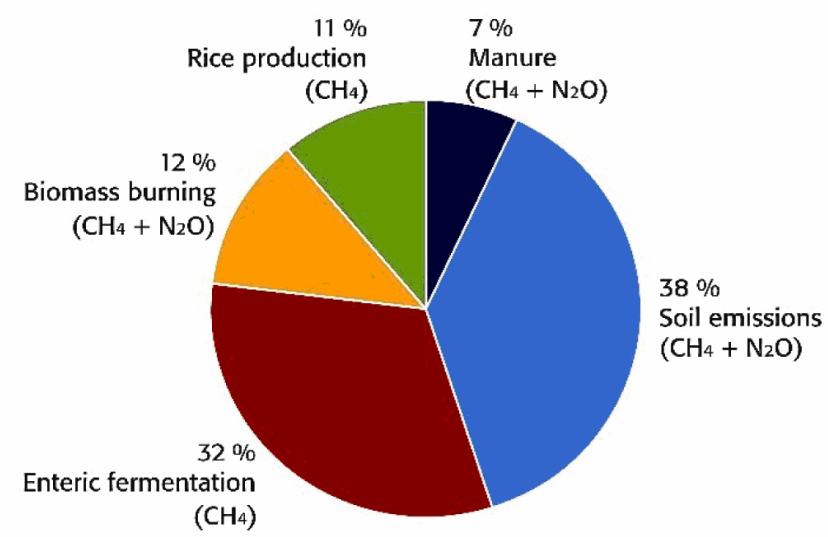

Table 1: Nepal's National Greenhouse Gas Inventory in 1994/95 (Gg) (MoEST, 2008)

\begin{tabular}{|c|c|c|c|c|}
\hline $\begin{array}{c}\text { Greenhouse Gas } \\
\text { (Source and Sink Categories) }\end{array}$ & $\begin{array}{l}\mathrm{CO}_{2} \\
\text { Emission }\end{array}$ & $\begin{array}{c}\mathrm{CO}_{2} \\
\text { Removal }\end{array}$ & $\begin{array}{c}\mathrm{CH}_{4} \\
\text { Emission }\end{array}$ & $\begin{array}{l}\mathrm{N}_{2} \mathrm{O} \\
\text { Emission }\end{array}$ \\
\hline 1. Energy & 1465 & & 71 & 1 \\
\hline 2. Industrial Processes & 165 & & & \\
\hline 3. Agriculture & & & 867 & 29 \\
\hline 4. Land Use Change \& Forestry & 22895 & -14778 & & \\
\hline 5. Wastes & & & 10 & 1 \\
\hline Total emission and removal & 24525 & -14778 & 948 & 31 \\
\hline Net emission & 9747 & & 948 & 31 \\
\hline
\end{tabular}

Table 2: General impacts on biophysical and socio-economic areas

\begin{tabular}{|l|l|}
\hline Biophysical impacts & Socio-economic impact \\
\hline $\begin{array}{l}\text { Physiological effects on crop, pasture, } \\
\text { forest and livestock (quantity and } \\
\text { quality) }\end{array}$ & $\begin{array}{l}\text { Decline in yield and } \\
\text { production }\end{array}$ \\
\hline $\begin{array}{l}\text { Change in land, soil and water } \\
\text { resources }\end{array}$ & $\begin{array}{l}\text { Reduced marginal GDP from } \\
\text { agriculture }\end{array}$ \\
\hline $\begin{array}{l}\text { Increased weed and pest challenges } \\
\text { Shifts in spatial and temporal } \\
\text { distribution of impacts }\end{array}$ & $\begin{array}{l}\text { Fluctuation in world market } \\
\text { price }\end{array}$ \\
\hline $\begin{array}{l}\text { Sea level rise and changes to ocean } \\
\text { distribution of trade regimes }\end{array}$ \\
\hline $\begin{array}{l}\text { Sea temperature rise causing fish to } \\
\text { inhabit in different ranges. }\end{array}$ & $\begin{array}{l}\text { Increased number of people } \\
\text { at risk of hunger and food } \\
\text { security }\end{array}$ \\
\hline
\end{tabular}




\section{CLIMATE CHANGE AND ITS IMPACTS ON AGRICULTURE}

According to the nature of impact of climate change on agriculture, Food and Agriculture Organization (2007) ha

s divided into two groups i.e.Biophysical and socio-economic (Table 2).

\section{IMPACTS ON PLANT PRODUCTION}

The impacts presented in Table 2 are generally negative. However, while looking critically on plant production, the climate change has both positive and negative impacts. Rises in temperature, for example, would help to grow crops in high altitude areas and towards the poles. In these areas, increases in temperature extend the length of the potential growing season, allowing earlier planting, early harvesting and opening the possibility of completing two crop cycles in the same season. The warmer conditions support the process of natural decomposition of organic matter and contribution the nutrient uptake mechanisms. The process of nitrogen fixation, associated with greater root development, is also predicted to increase in warmer conditions and with higher $\mathrm{CO}_{2}$, if soil moisture is not limiting.

Increases in temperature, at the same time, might affect lower altitude areas (in Nepal, the Terai and foothills) where temperatures are already high. Higher temperatures affect both the physical and chemical properties in the soil. Increased temperatures may accelerate the rate of releasing $\mathrm{CO}_{2}$ resulting in less than optimal conditions of net growth. When temperatures exceed the optimal level for biological processes, crops often respond negatively with a steep drop in net growth and yield. Heat stress might affect the whole physiological development, maturation and finally yield of cultivated crops.

Higher temperatures provide a conducive-environment for the majority of insect pests. Longer growing seasons, higher night temperatures, and warmer winters help insect pests undergo multiple life-cycles and increase the chances of affecting plant production.

Change in climate affects the pattern and extent of rainfall and evapotranspiration processes which affect soil moisture storage, run-off, and water absorption by the plant. Both lack of and access to water might affect the different stages of plant production. Moisture stress during flowering, pollination, and grain-filling stage is harmful to most crops. Increased evaporation from soil and accelerated transpiration in the plants themselves will cause moisture stress.

Researches have shown that increased concentration of $\mathrm{CO}_{2}$ in the atmosphere increases the likelihood of higher absorption of $\mathrm{CO}_{2}$ inside the plant through stomata during photosynthesis which provides carbohydrates for plant growth. Crop species vary in their response to $\mathrm{CO}_{2}$ according to their physiological class i.e. $C_{3}$ versus $C_{4}$ plants.

\section{CLIMATE CHANGE, FOOD AND PEOPLE'S LIVELIHOODS}

The developing world already contends with chronic poverty and food crisis. Climate change presents yet another significant challenge to be met. The estimate for Africa is that $25-42 \%$ of species habitats could be lost, affecting both food and non-food crops. Habitat change is already underway in some areas, leading to species range shifts and changes in plant biodiversity which includes indigenous foods and plant-based medicines. In developing 
countries, $11 \%$ of arable land could be highly affected by climate change. There will be a reduction of cereal production in 65 countries and retardation of about $16 \%$ of agricultural GDP (FAO, 2007). IPCC (2007a) has predicted a decrease of $30 \%$ in food production in South Asia. The major findings of IPCC are presented in Box 1.

Climate change will have serious impacts on world economic output, human life and the environment throughout the world. The most vulnerable - the poorest countries and populations - will, however, suffer earliest and most, even though they have contributed least to the causes of climate change (HM Treasury, 2009). Poor people who depend on agriculture are the most vulnerable to climate change. Increasing crop failures and livestock deaths are already imposing high economic losses and undermining food security. More frequent droughts and increasing water scarcity may devastate large parts of the tropics and undermine irrigation and drinking water in entire communities of already poor and vulnerable people (World Bank, 2009. The increased frequency and extent of floods, droughts and land cutting has rendered the agriculture sector more vulnerable and reduced the productivity of land and of the potential for plant production. The case is much more severe in countries like Nepal where people have inadequate knowledge, weak governance systems and fewer resources to respond.

\section{ORGANIC AGRICULTURE AND GHGS EMISSIONS}

Organic agriculture not only enables agriculture-influenced ecosystems to better adjust to the effects of climate change but also offers potential to reduce the emissions of agricultural greenhouse gases.

Mitigation is a process of reducing Green House Gases (GHGs) which are responsible for change in climate and climatic variability. The main GHGs include methane, nitrous oxide and carbon dioxide.

Organic agriculture not only enables ecosystems to better adjust to the effects of climate change but also offers potential to reduce the emissions of agricultural greenhouse gases. In organic agriculture, soil fertility is maintained mainly through farm internal inputs (organic manures, legume production, wide crop rotations etc.); energy-demanding synthetic fertilizers and plant protection agents are rejected; and there is less or no use of fossil fuel. The carbon sink idea of the Kyoto Protocol (Article 3.4) may therefore partly be accomplished efficiently by organic agriculture (Food and Agriculture Organization, 2008). In order to reduce GHG emissions from the agriculture sector, suggestions by IPCC (2007a) included improving crop and grazing land management to increase soil carbon storage; improving nitrogen fertilizer application techniques to reduce $\mathrm{N}$; and dedicated energy crops to replace fossil fuel use (IPCC, 2007b).

Research reveals that consumption of fossil fuels in organic agriculture is about half that of conventional agriculture. In organic agriculture, almost $70 \%$ of $\mathrm{CO}_{2}$ emissions were due to fuel consumption and the production of machinery, while in conventional systems $75 \%$ of the $\mathrm{CO}_{2}$ emissions are ascribed to $\mathrm{N}$-fertilizers, feedstuff and fuels (Food and Agriculture Organization, 2008).

The main factors responsible for lower emission of $\mathrm{CO}_{2}$ from organic agriculture are maintenance and increase of soil fertility by the use of farmyard manure, the omission of 
synthetic fertilizers and synthetic pesticides; and the lower use of energy-intensive animal feeds.

Sustainable agricultural strategies comprising recycling of organic matter, tightening internal nutrient cycles, and low- or no-tillage practices may rebuild organic matter levels and reduce losses from the system. A report estimated that a $20 \%$ increase in soil organic matter as a result of organic agriculture would result in a decrease of about 9 tonnes of carbon emission per hectare (Food and Agriculture Organization, 2008).

The avoidance of synthetically-produced mineral nitrogen in organic agriculture confines productivity within natural limits (i.e. $\mathrm{N}$-fixation) or the limits defined by the annual nutrient balance of the farm, including imported fodder and organic fertilizers. Organic agriculture, therefore, is likely to emit less $\mathrm{N}_{2} \mathrm{O}$ because of:

- a systemically lower $\mathrm{N}$-input;

- less $\mathrm{N}$ from organic manure due to lower livestock densities;

- a higher $\mathrm{C} / \mathrm{N}$ ratio in applied organic manure and less available mineral nitrogen in the soil as a source for denitrification;

- the permanent plant cover in organic systems which results in a more efficient uptake of mobile nitrogen in soils, thus reducing the potential risk for $\mathrm{N}_{2} \mathrm{O}$ emissions.

However, some researches have shown that organic agriculture is more likely to produce and release nitrous oxide in the environment due to the use of much more organic manure from livestock.

Very little information is available in relation to organic agriculture and methane. The emission of methane by ruminants is probably not affected by organic production. The higher proportion and lower productivity of ruminants in organic agriculture may, however, lead to slightly higher emissions of $\mathrm{CH}_{4}$.

In general, research shows significant reductions of GHGs especially $\mathrm{CO}_{2}$ and $\mathrm{N}_{2} \mathrm{O}$ from organic agriculture. However, importantly for countries such as Nepal, there is no information or research data related to subsistence farming systems and different types of conventional as well as organic agriculture to compare among different farming systems.

\section{CLIMATE CHANGE ADAPTATION AND ORGANIC AGRICULTURE}

IPCC (2001) defines adaptation to climate change specifically as "adjustment in natural or human systems in response to actual or expected climatic stimuli or their effects, which moderates harm or exploits beneficial opportunities. Various types of adaptation can be distinguished, including anticipatory and reactive adaptation, private and public adaptation, and autonomous and planned adaptation."

It is reported that organic agriculture could be a resilience systems for adaptation to climate change. Organic agriculture helps to increase resilience of farming systems through better management of soil and water, promoting biodiversity and strengthening community knowledge systems. Organic agriculture provides better results in many aspects of environmental issues compared to conventional agriculture (Food an Agriculture Organization, 2008). 


\section{SOIL AND WATER RESOURCES MANAGEMENT}

Soil and soil management are the foundation of organic production. Organic growing systems are soil-based which care for the soil and surrounding ecosystems and provide support for a diversity of species, while encouraging nutrient cycling and mitigating soil and nutrient losses. Organic farming returns microbial plant or animal material to the soil to increase or at least maintain its fertility and biological activity. It also manages the water resources judiciously. Hence, healthy soil and proper use of water resources would help for effective adaptation process.

\section{ORGANIC AGRICULTURE AND BIODIVERSITY}

Organic agriculture utilizes various combinations of plant and animal species in time and space. Some organic systems are more diverse than others. Crop rotations (i.e. diversity in time) are a requirement of organic standards. Crop rotations are the most basic and common form of diversity on organic farms. Organic farmers rotate crops and livestock from one part of the farm to another rather than growing the same product over and over in the same space. This practice provides multiple benefits for soil quality, helps to break pest and disease life cycles and maximizes efficient use of soil nutrients and water. Some farmers also use multiple sowing dates, thereby lessening the chance that the whole crop will be at a critical stage during an extreme weather event (Food and Agriculture Organization, 2008).

Organic standards also require farmers to use organic seeds and encourage genetic diversity in both crops and livestock. Organic farmers are expected to save their seeds year after year, making them self-sufficient and self-reliant. It is thus vital in developing countries particularly in the regions where farmers cannot afford to buy their own seed. Farmers select seeds from successful plants and in so doing develop local landraces that are highly adaptable to local ecosystems.

The combination of these activities increases farms' resemblance to natural ecosystems, thereby enhancing resilience. Agricultural biodiversity in time and space increases resilience in a myriad of ways: complementary use of soil nutrients and water, increased total productivity through appropriate polyculture mixtures, decreased risk from one crop failure, pest protection, the creation of microclimates suitable for beneficial insects and strengthening the genetic traits of local landraces.

\section{COMMUNITY KNOWLEDGE SYSTEMS}

Organic agriculture is based on ecological processes; knowledge of the agro-ecosystem is thus a pre-requisite to any organic farm. Farmers with a traditional knowledge base are potentially better able to develop ecological processes to respond to the effects of climate change.

Community knowledge represents a process of learning as much as a single body of information. Traditional knowledge is not just a system for the present, but a source of institutional memory about what practices have worked best over time. Such knowledge has been described as a "reservoir of adaptations," a whole set of practices that may be used again if the need arises (Food and Agriculture Organization, 2008). 
Organic agriculture promotes improved soil quality and efficient water use, agro-ecosystems and strong community knowledge processes which in turn help to improve farm resilience against the adverse impacts of climate change and strengthen farms' adaptive capacity.

\section{ECOSYSTEMS GOODS AND SERVICES}

Organic agriculture provides a basis for maintaining environmental goods and services at the farm and landscape level. According to Food and Agriculture Organization (2008), organic agriculture provides the following environmental goods and services.

Table 3: organic agriculture and environmental goods and services

\begin{tabular}{|c|c|}
\hline Areas & Environmental goods and services \\
\hline Soil & $\begin{array}{l}\text { Organic matter content is usually higher in organically-managed soils, indicating } \\
\text { higher fertility and stability of organic soils as well as moisture retention capacity, } \\
\text { which reduce the risk of erosion and desertification. } \\
\text { Organically-farmed soils have significantly higher biological activity and a higher } \\
\text { total mass of micro-organisms, making for more rapid nutrients recycling and } \\
\text { improved soil structure. While the proportion of soluble nutrient fractions is lower } \\
\text { on organically managed soils, there is no decrease in organic yields since higher } \\
\text { biological activity and higher mycorrhizal root colonization counteract nutrient } \\
\text { deficiency. }\end{array}$ \\
\hline Water & $\begin{array}{l}\text { Organic agriculture poses no risk of ground and surface water pollution through } \\
\text { synthetic pesticides. }\end{array}$ \\
\hline Air & $\begin{array}{l}\text { Organic agriculture enables ecosystems to better adjust to the effects of climate } \\
\text { change and has a major potential for reducing agricultural greenhouse gas } \\
\text { emissions. } \\
\text { Organic agricultural strategies, by recycling organic matter and tightening internal } \\
\text { nutrient cycles, contribute to carbon sequestration. }\end{array}$ \\
\hline Energy & $\begin{array}{l}\text { Organic agriculture performs better than conventional agriculture on a per } \\
\text { hectare scale, both with respect to direct energy consumption (fuel and oil) and } \\
\text { indirect consumption (synthetic fertilizers and pesticides). } \\
\text { Efficiency of energy use of organic farms is high. }\end{array}$ \\
\hline $\begin{array}{l}\text { Bio- } \\
\text { diversity }\end{array}$ & $\begin{array}{l}\text { Agriculture genetic resources, including also insects and micro-organisms, have all } \\
\text { been shown to increase when land is farmed organically. } \\
\text { Wild flora and fauna within and around organic farms are more diverse and } \\
\text { abundant than in conventional or integrated agriculture. }\end{array}$ \\
\hline $\begin{array}{l}\text { Ecological } \\
\text { services }\end{array}$ & $\begin{array}{l}\text { Organic agriculture offers vast food resources and shelter for beneficial } \\
\text { arthropods and birds, thus contributing to natural pest control. } \\
\text { Organic agriculture contributes to the conservation and survival of pollinators, } \\
\text { thanks to the banning of synthetic chemical pesticides and herbicides and the } \\
\text { enhanced ecosystem diversity }\end{array}$ \\
\hline
\end{tabular}


Organic agriculture promotes ecological resilience, improved biodiversity, healthy management of farms and the surrounding environment, and builds on community knowledge and strength. Hence, organic agriculture has been proved to be effective for enhanced adaptive capacity of farmers adversely affected by climate change.

\section{IMPLICATIONS AT NATIONAL LEVEL IN NEPAL}

Despite the alarming impacts-both potential and realized of climate change on agriculture, there is hardly any information available related to climate change, agriculture and organic agriculture in Nepal. Organic agriculture is beginning to gain attention both in the Government and in the non-government sector these days. The Ministry of Agriculture and Cooperatives (MOAC) through its district level offices has started working in organic agriculture but the efforts are still not adequate. The ministry has already finalized the organic agriculture standard for certification for Nepal.

The Government of Nepal through the Ministry of Environment Science and Technology (MoEST) is going to prepare a National Adaptation Programme of Action (NAPA) for Nepal. Though it is not yet clear how the government is going to prepare the NAPA, the involvement of MoAC and other non-governmental organizations in the process of NAPA formulation is vital for the integration of organic agriculture and adaptation related issues.

\section{CONCLUSION}

Although there is very little information available related to organic agriculture and its associations with climate change mitigation and adaptation in Nepal, this review of international literature reveals that organic agriculture could support both GHGs emissions reduction as well as the development of resilient farming systems for adaptation. It is imperative to bring this issue to the forefront of discussions by government and nongovernment sectors to assess the potential contribution of organic agriculture to the climate change mitigation and adaptation process. Involvement of appropriate partners is crucial while preparing national and regional climate change related plans and policies including the NAPA for Nepal.

\section{REFERENCES:}

Food and Agriculture Organization, 2007. Adaptation to climate change in agriculture, forestry and fisheries: perspective, framework and priorities, Food and Agricultural Organization of the United Nations, Rome 2007 pp 2

Food and Agriculture Organization, 2008. Organic agriculture and climate change. Retrieved on Jan 10, 2009 from http://www.fao.org/DOCREP/005/Y4137E/y4137e02b.htm\#89.

HM Treasury, 2009. Stern Review: The Economics of Climate Change- Summary of conclusion. Retrieved on Jan 10, 2009 from http: / /www.hmtreasury.gov.uk/d/CLOSED_SHORT_executive_summary.pdf

IPCC, 2001. Climate Change 2001: Impacts, Adaptation and Vulnerability, Summary for Policy Makers, WMO.

IPCC, 2007. Third assessment report mitigation' IPCC, Switzerland.

IPCC, 2007. Contribution of Working Group II to the Fourth Assessment Report of the Intergovernmental Panel on Climate Change - Summary for Policymakers. Retrieved on Nov 10, 2008 from http://www.ipcc.ch/pdf/assessment-report/ar4/wg2/ar4-wg2-spm.pdf 
MOEST, 2008. National Capacity Self -Assessment for Global Environment Management Nepal Stocktaking report: climate change: Jan, 2008. Ministry of Environment Science and Technology, Nepal.

MoPE, 2004. Nepal Initial National Communication to the Conference of the Parties of the United Nations Framework Convention on Climate Change. Ministry of Population and Environment, 2004.

Organic Consumer Association, 2008. Organic agriculture can help stabilize global climate change. retrieved on Nov 10, 2008 from http://www.organicconsumers.org/organic/stabalize062404.cfm

Research Institute of Organic Agriculture, 2008. Organic agriculture and climate change: A monograph by UNCTAD and FIBL. Retrieved on Nov 11, 2008 from www.intracen.org/Organics/documents/Organic_Farming_and_Climate_Change.pdf

World Bank, 2008. Agriculture for development policy brief: adaptation and mitigation of climate change in agriculture: World Development Report 2008. Retrieved on Nov 8, 2008 from http://siteresources.worldbank.org/INTWDR2008/Resources/Brief_AdptMitClimateChng_web.pdf

World Bank, 2009. Agriculture for Development, Overview. Retrieeved on Jan 10, 2009 from http://siteresources.worldbank.org/INTWDR2008/Resources/2795087-1192111580172/WDROver2008-ENG.pdf 